\title{
Indigenous knowledge, women and issues of sustainable development
}

\author{
B. G. Ndawonde, E. T. Dlamini \& S. N. Imenda \\ University of Zululand, South Africa
}

\begin{abstract}
This paper reports the results of the study that investigated the kinds of medicinal plants sold by medicinal plant sellers at bus ranks in northern KwaZulu-Natal (South Africa). Among the aims of the research was to explore who the participants in the medicinal plant selling business are. The study also investigated the kinds of species that are harvested, methods of harvesting and what the medicinal plant species are used for. Since medicinal plant sellers use the medicinal plant selling business for their livelihoods, the study also investigated whether conduction of the business was profitable and environmentally sustainable. Data was collected through site visits, structured face-to-face interviews and a workshop. The results showed that the medicinal plant selling business is dominated by poor, elderly black rural women who use unsustainable methods of harvesting and selling. The study also confirmed that Africans still rely heavily on traditional medicine. The use of this type of indigenous knowledge is thriving, but unfortunately the issue of sustainable harvesting of medicinal plants is not considered. For ethical reasons and for promotion of sustainable development of rural communities, the researchers are now working with the medicinal plant sellers in an effort to teach them how to cultivate medicinal plants in their own communities. This would prevent exposing women to collecting plants in dangerous places and also from depleting medicinal plants in their natural environments. This can protect medicinal plants from being harvested to extinction.

Keywords: sustainable development, rural Black women, indigenous knowledge and medicinal plants seller.
\end{abstract}




\section{Introduction}

Traditionally, women have been mainstays of medicinal plants based activities. These typically include medicinal plants being collected and transported to the market. This is confirmed by studies conducted by Macía et al. [1] on the ethnobotanical survey of medicinal plants commercialised in the markets of La Paz and El Alto, Bolivia who found that there were more women selling medicinal plants than men. Silori and Badola [2] discovered that there were gender imbalances on medicinal plants trade in Western Himalaya where women dominated. In South Africa the same gender patterns in medicinal plants selling were observed. For example, a case study on medicinal plant selling in northern KwaZulu-Natal showed that there were more women medicinal plant sellers than men (Ndawonde et al. [3]). Studies by Williams et al. [4] at Faradays medicinal plant market, in Gauteng province showed that there were $75 \%$ of women and 25\% men selling medicinal plants. In Durban Market, Mander [5] found that there were many women from KwaZulu-Natal who left their families for long periods to sell medicinal plants in markets. This shows that medicinal plant selling has assured that many poverty stricken people, particularly women, support their families from profit of selling and gathering the plant species. The research had the following objectives, to:

- determine socio-economic characteristics of respondents involved in selling medicinal plants.

- $\quad$ explore prevalent challenges of the medicinal plant selling business, and also

- find out opportunities and constraints for conservation of medicinal plants.

\section{Research methodology}

The study was conducted in the five sites in northern KwaZulu-Natal, namely, Empangeni, Richards Bay, Mtubatuba, Mahlabathini and Nongoma. Data which sought personal information about those engaged in the medicinal plant business, their gender, age and selling location was collected by means of a questionnaire. Other information included: the names of the plant species, the uses of the medicinal plants, and the parts of the plants that were used. Questions on harvesting methods, the names of plants in high demand but rare to find were collected using semi-structured interviews. This type of interview was recommended because it allows the researcher to probe further with questions where clarity is needed. The interviews were conducted in IsiZulu and the information was translated into English. The plants were given scientific names using Hutchings [6] and Pooley [7]. The conservation status of the plants was checked using South Africa Red Data List by Golding [8].

A survey on the collection of the prices of medicinal plants sold in standard $50 \mathrm{~kg}$ and $25 \mathrm{~kg}$ bags was conducted at Mona. That was done by recording the prices of the plant materials that were packed in the bags in order to find out how much profit could be generated by medicinal plant sellers per sub-sample of the 
plant material. A workshop was organised for the medicinal plant sellers to address the areas of concern. The following section shows the presentation of data.

\section{Results}

Figure 1 below shows how the gender of the respondents was represented at the different sites where medicinal plants were sold.

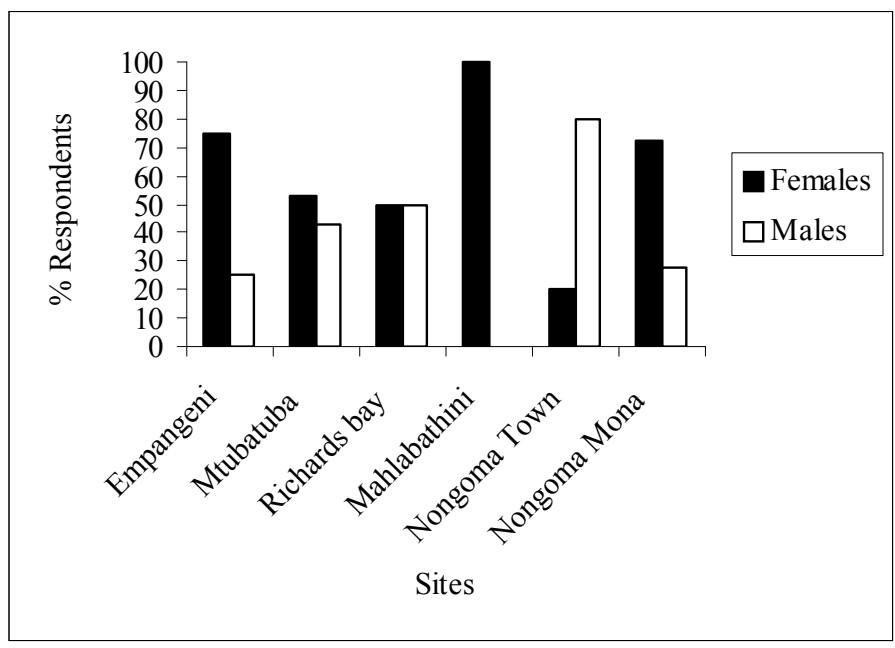

Figure 1: Gender distribution of the medicinal plant sellers $(n=63)$.

The study showed that medicinal plant sellers were mainly females. Out of the 63 different participants who were interviewed, $77 \%$ were females and $23 \%$ males. The finding that medicinal plant selling entrepreneurs are women was not surprising. For obvious reasons, women are found in large numbers in poorly paid jobs.

The age groups of medicinal plant sellers are represented in figure 2 which shows that the dominant age group in this business ranged from $45-54$ years. This is the age group that consists of mothers, many of whom are single and struggling to feed and educate their children. There is not much respect and dignity in selling medicinal plants, which is why young people are not interested in pursuing it as a livelihood.

The majority of the plant sellers' ages ranged from 45-54 at all the sites. This indicates that more plant sellers are elderly people, with only a few young ones. The reason is that elders had knowledge of medicinal plants. This was confirmed by Zobolo and Mkabela [9] from whose study it becomes clear that the older females have a greater knowledge of medicinal plants than girls do.

The majority of the plant sellers' ages ranged from 45-54 at all the sites. This indicates that more plant sellers are elderly people, with only a few young ones. The reason is that elders had knowledge of medicinal plants. This was confirmed by Zobolo and Mkabela [9] from whose study it becomes clear that the older females have a greater knowledge of medicinal plants than girls do. 


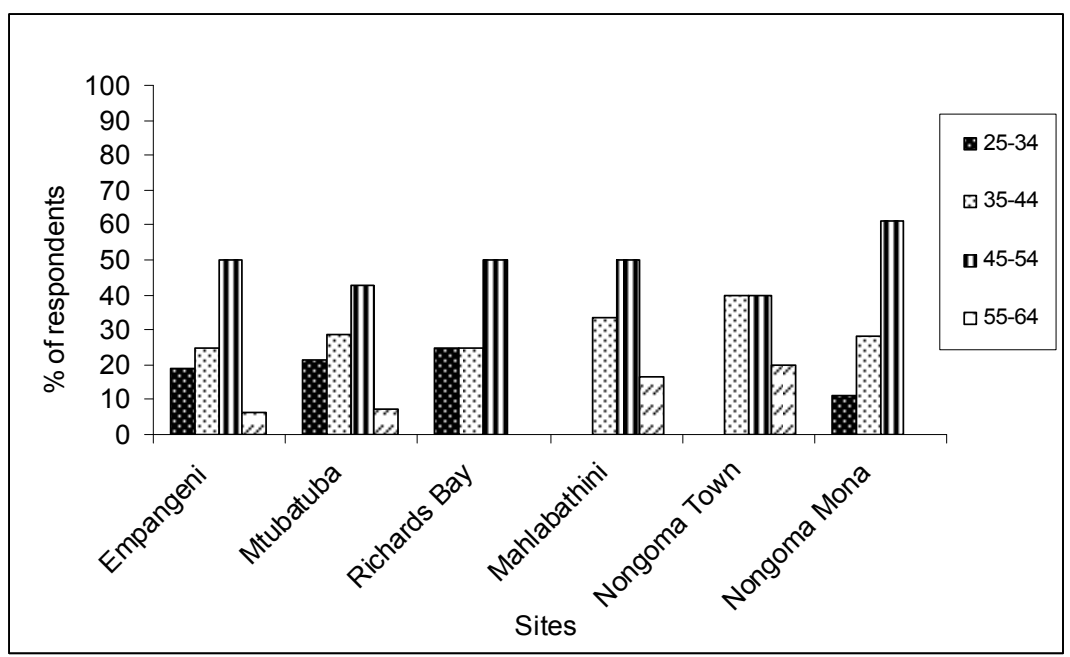

Figure 2: $\quad$ Age of medicinal plant sellers $(n=63)$.

\section{Medicinal plant distribution patterns}

The medicinal plant distribution in different sites is shown in figure 3 up to figure 7. Only medicinal plant species that had an average percentage distribution above $50 \%$ were considered. That was to cater for graph plotting since there was a high number of medicinal plant species that were recorded during the study. The bars in the following graphs indicate standard errors.

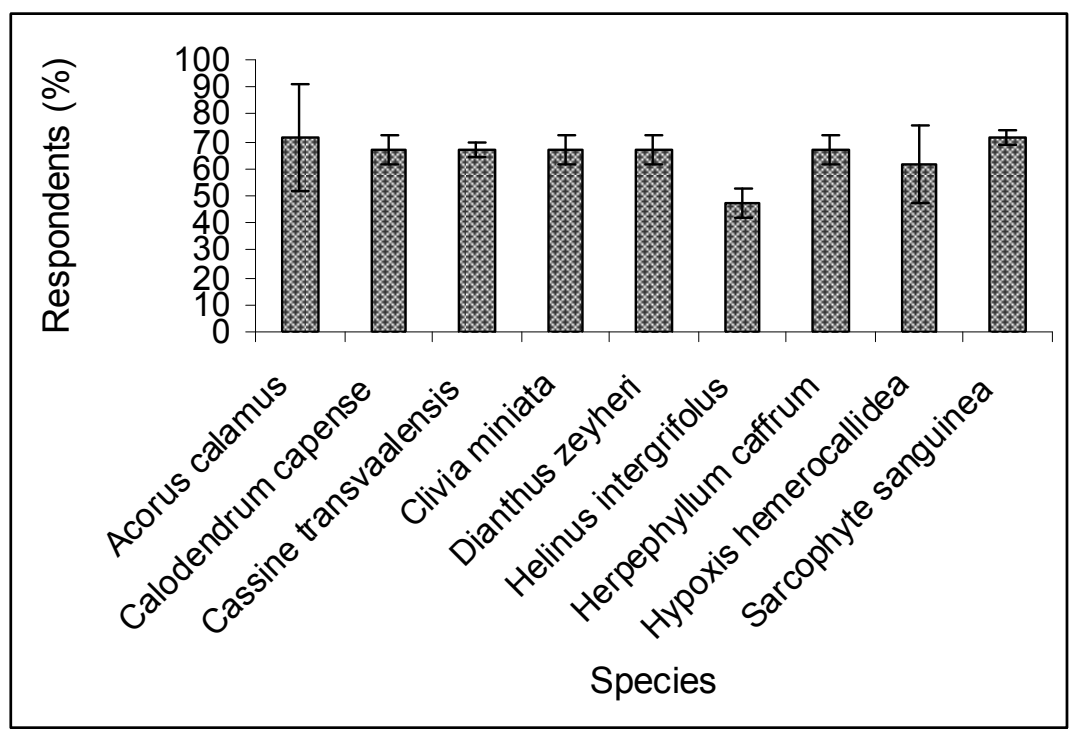

Figure 3: $\quad$ Medicinal plant distribution at Empangeni. 
The dominant medicinal plant species distributed at Empangeni were Acorus calamus and Sacophyte sanguinea (70\%) respectively. Empangeni is a small town in northern KwaZulu-Natal. The town is nearby an industrial area Richards Bay. Emissions from industries may cause people of this area to suffer from sinusitis. That could be the reason for Acorus calamus being sold the most since it is believed to cure influenza. The medicinal plant distribution in Richards Bay, which is in the nearby geographical location to Empangeni, is given in figure 4.

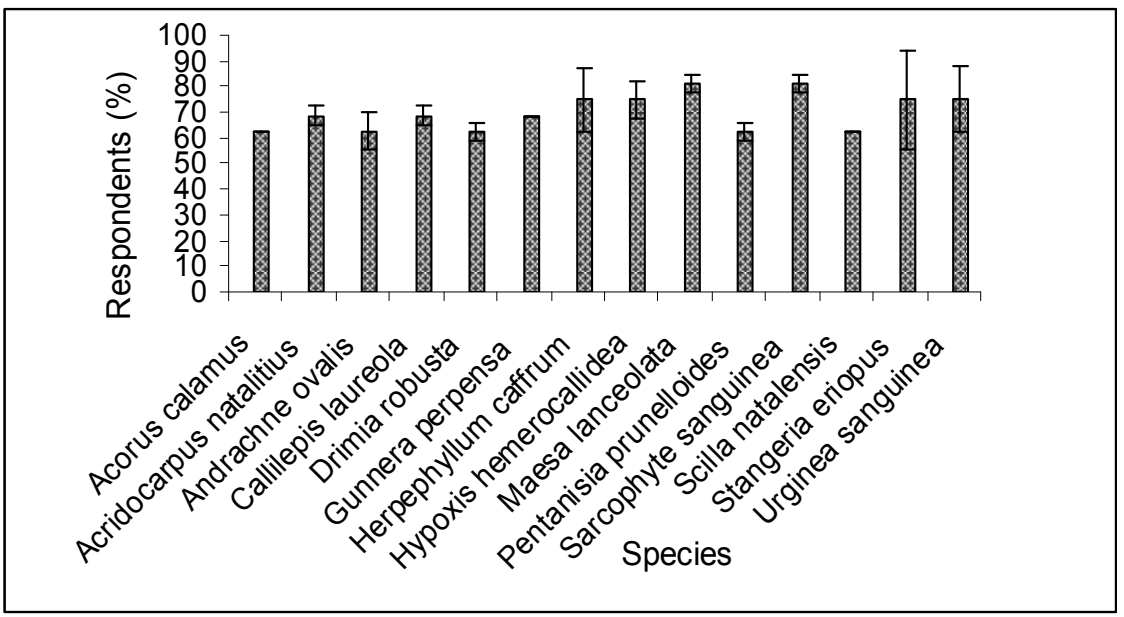

Figure 4: Medicinal plants species distribution at Richards Bay.

The species with high sales from Richards Bay were Maesa lanoellidae, Sarcophyte sanguinea and Stangeria eriopus and Hypoxis hermerocallidae. Sarcophyte sanguinea was also in demand in Empangeni. That could be also because the medicinal plant species is believed to bring luckiness. People from different areas, for instance, Mtubatuba go to seek for jobs in Richards Bay. They may believe that the use of Sarcophyte sanguinea could help them to get jobs. The medicinal plant species obtained from Mtubatuba are given in figure 5 .

At Mtubatuba (another small town) the species that had high sales were Acridocarpus natalitus, Albizia adiantifolia, Hypoxis hemerocallidae, Indigoferra frutescens and Scabioca columbara. These species were different from those that were high in demand in Richards Bay and Empangeni. These differences may account for preferences of particular medicinal plants, based on what is available in different areas.

Adenia gummifera, Cassine transaalensi, Sacorphyte sanguine and Scilla natalensis were the dominant species at Mahlabathini, an area which had different dominant species than other sites. That gave an idea that although the demand of a particular species could be regional but what determines the availability of medicinal species could be the demands of customers in a particular area. Figure 7 shows the percentages of plant species in Mona market in Nongoma. 


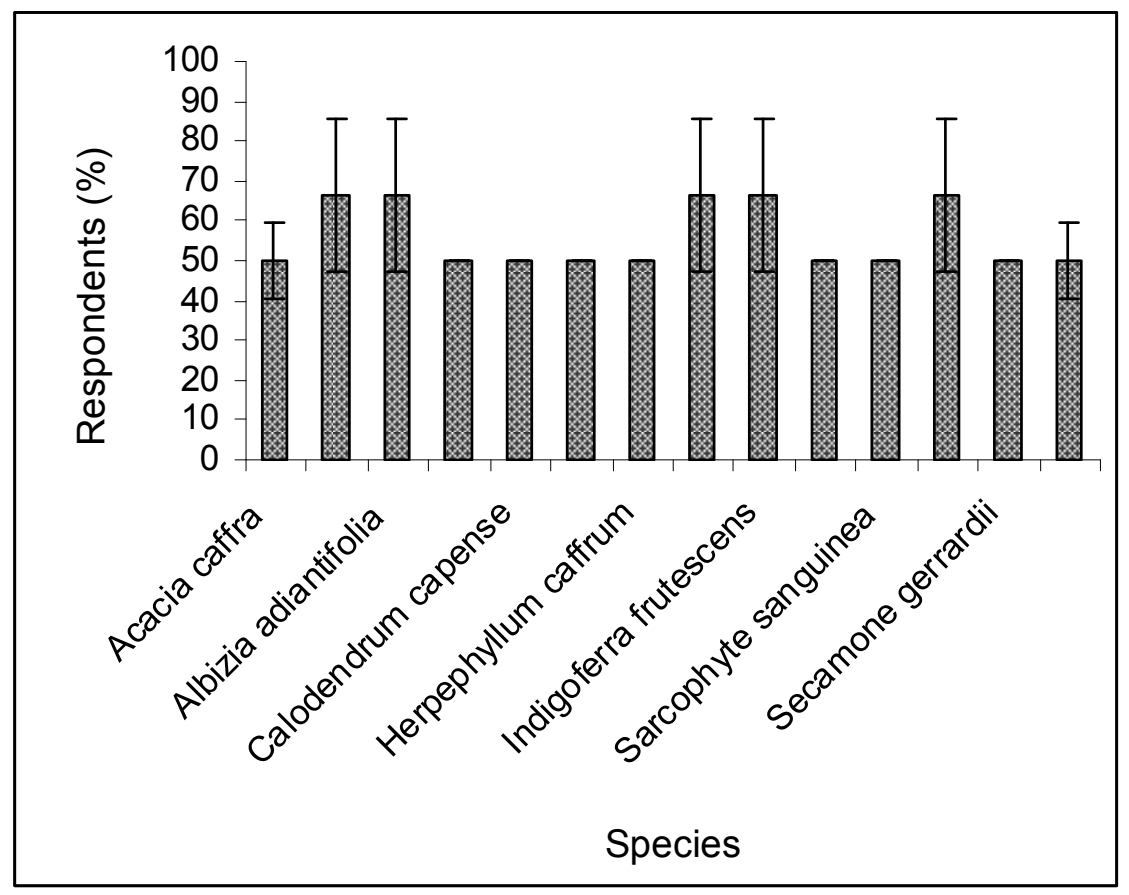

Figure 5: Medicinal plant species distribution at Mtubatuba.

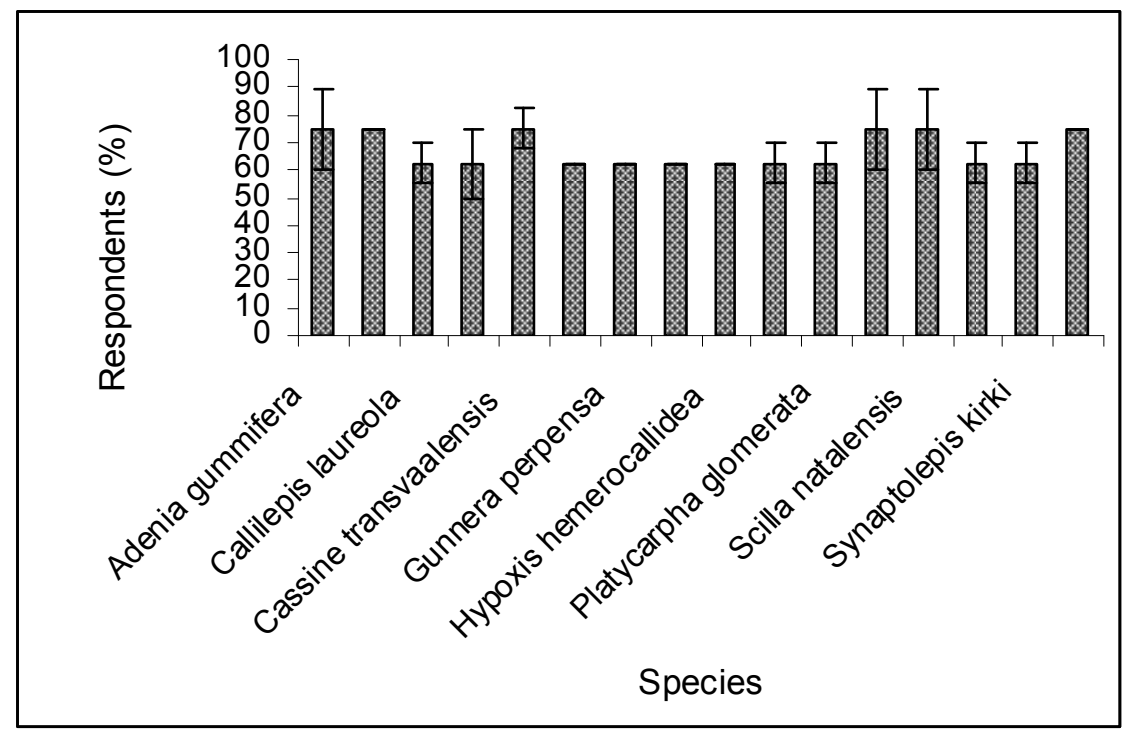

Figure 6: Medicinal plant species distribution at Mahlabathini. 


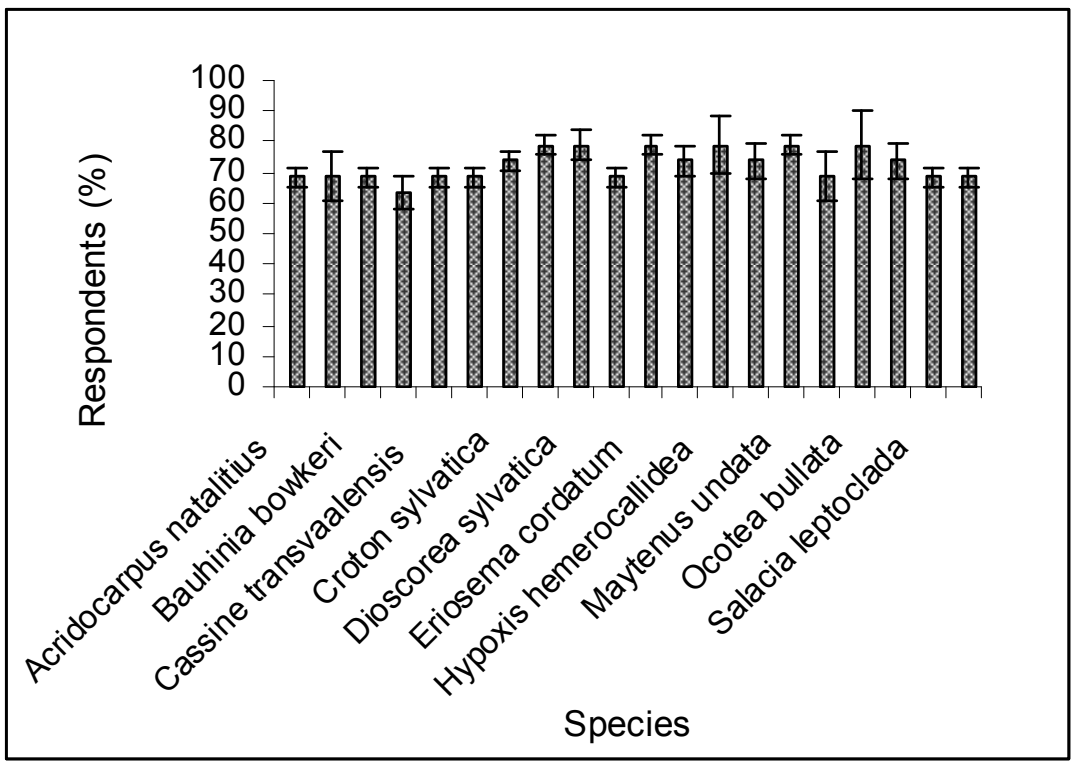

Figure 7: Medicinal plant species distribution at Mona-Nongoma.

The medicinal plant species mentioned above were also dominant in Mona. That was because Mona is a wholesale selling point of medicinal plants in Nongoma. Medicinal plants were harvested in various places in order to be sold in Mona.

The medicinal taxon -Hypoxis hemerocallidae was in high demand in all the sites. This could be due to that the plant is believed to treat sexually transmitted diseases such as HIV/AIDS, which is a concern for every person. This might be an indication of the people's desperate need for the cure of the diseases that prevailed at the time when the research was conducted.

The results on quantities of material traded and pricing are given table 1. It would appear that the medicinal plant sellers harvested the plants at low returns. Some of the plants in table 1 such as Hypoxis hemerocallidae and Ocotea bullata are in the Red Data List by Goldings [8] but the sub-sample cost five rands. The most important consideration for the plant sellers seemed to be the satisfaction of their immediate needs - a situation that is clearly unsustainable. It was found that two hands full of medicinal plant material cost R5.00. It is obvious that the hands of the sellers are not equal in size therefore they need a standard unit of measurement. One seller can therefore sell more merchandise at a higher price whereas another with bigger hands would sell more material at the same price. If the transportation fee, time, work effort (in chopping up the plant material) and the risk of collecting the plants in the veld is considered, a maximum price of R140.00 per 50kg bags would not yield sufficient profit.

The following section below illustrates briefly how the workshop with the medicinal plant sellers was used to discuss issues in the medicinal plant selling business. 
Table 1: The quantities of certain herbal medicines sold in Nongoma (Mona bulk sale) in Northern KwaZulu-Natal region and income generated by traders in standard $50 \mathrm{~kg}$ bags.

\begin{tabular}{|c|c|c|c|c|c|}
\hline Scientific name & Part used & $\begin{array}{c}\text { Sub- } \\
\text { sample } \\
\text { (g) }\end{array}$ & $\begin{array}{c}\text { Price } \\
(\mathrm{R}) \\
\text { charged }\end{array}$ & $\begin{array}{c}50 \mathrm{~kg} \\
\text { and } \\
25 \mathrm{~kg} \\
\text { size } \\
\text { maize } \\
\text { bags }\end{array}$ & Price (R) \\
\hline Acorus calamus & rhizomes & 207.09 & 5.00 & 25 & 60.00 \\
\hline $\begin{array}{c}\text { Acridocarpus } \\
\text { natalitus }\end{array}$ & leaves & 694.62 & 5.00 & 50 & 120.00 \\
\hline Aptenia cordifolia & bark & 65.72 & 5.00 & 25 & 30.00 \\
\hline Callilepis laureola & bark & 295.27 & 5.00 & 50 & 100.00 \\
\hline $\begin{array}{c}\text { Calodendrum } \\
\text { capense }\end{array}$ & bark & 235.52 & 5.00 & 25 & 60.00 \\
\hline $\begin{array}{c}\text { Capparis } \\
\text { tementosa } \\
\end{array}$ & bark & 127.79 & 5.00 & 25 & 40.00 \\
\hline $\begin{array}{c}\text { Chlorophytum } \\
\text { modestum }\end{array}$ & roots & 562.40 & 5.00 & 25 & 50.00 \\
\hline Cliva minnata & $\begin{array}{l}\text { whole } \\
\text { plant }\end{array}$ & 194.49 & 5.00 & 50 & 70.00 \\
\hline Conia capensis & $\begin{array}{l}\text { whole } \\
\text { plant }\end{array}$ & 146.21 & 5.00 & 50 & 100.00 \\
\hline Drimia robusta & bulb & 207.09 & 5.00 & 25 & 60.00 \\
\hline $\begin{array}{c}\text { Erythrophyleum } \\
\text { lasianthum }\end{array}$ & roots & 350.94 & 5.00 & 50 & 100.00 \\
\hline $\begin{array}{c}\text { Hypoxis } \\
\text { hermellocallidae }\end{array}$ & bulb & 694.62 & 5.00 & 50 & 120.00 \\
\hline Mondia whitei & $\begin{array}{c}\text { bark/root } \\
\mathrm{s} \\
\end{array}$ & 14.10 & 5.00 & 50 & 140.00 \\
\hline Ocotea bullata & bark & 296.27 & 5.00 & 50 & 70.00 \\
\hline Olinia radifolia & roots & 146.11 & 5.00 & 50 & 80.00 \\
\hline $\begin{array}{c}\text { Sarcophyte } \\
\text { sanguinea }\end{array}$ & roots & 282.07 & 5.00 & 50 & 140.00 \\
\hline $\begin{array}{c}\text { Urginea } \\
\text { sanguinea }\end{array}$ & roots & 138.08 & 5.00 & 50 & 70.00 \\
\hline
\end{tabular}

\section{The informal workshop for medicinal plant sellers}

Having realised that medicinal plant sellers were harvesting in unsustainable way, a workshop was organised for them. The main aim of the workshop was to enable the researchers to help the sellers reflect on their harvesting methods and 
their effect on the environment. It was deemed necessary to alert the sellers that they should harvest plants wisely and think of future generations by taking corrective actions before many of the plants became extinct.

The fact that most of the workshop attendees were barely literate (that many of whom could hardly sign their names), indicates a high rate of early dropout from school. Adult illiteracy among Black people living in rural areas is high, as is poverty. As the researchers interacted with the medicinal plant sellers and as they opened up to discuss issues, it became clear that they were willing to learn and share their knowledge. Education and training of people have been viewed as the most powerful weapons in the fight against rural poverty and necessary for sustainable development.

Principles of sustainability entail not sacrificing the needs of future generations in order to meet the demands of the present. The researchers hoped that by sharing information with the medicinal plant sellers and by stimulating recognition of our overall responsibility to protect our natural resources, the latter would be able to motivate them to take action for their environment. One critical issue that was discussed with the plant sellers was whether they saw any of their children running successful medicinal plant selling businesses. The answer was obvious in that the rate at which the plants are harvested without being replenished, future generations will find some species extinct; hence they would not be able to run their business.

Another issue that was discussed with the medicinal plant sellers was the notion that indigenous knowledge, which is not shared freely but kept as a secret, could easily be lost when key individuals die. It was made clear that if knowledge is not passed from one generation to the next, there will be no heritage to talk about. The importance of documenting knowledge and skills of indigenous communities was underscored. The discussion highlighted the importance of sharing knowledge and wisdom publicly to benefit all humanity and to recognise the sources of such knowledge. In the informal workshop, the researchers aimed at creating space for social transformation among the plant selling communities, with the aim of taking them to a higher level of social responsibility.

\section{Conclusion}

Gorjestani [10] states that "Indigenous knowledge is an integral part of the culture and history of a local community. We need to learn from local communities to enrich the development process". Basically, what this means is that there are competing perspectives and world views from which to understand and make sense of the world. Expanding information and the involvement of different stakeholders is the key to solving environmental problems, which include political and socio-economic problems. Also, owing to the prevalence of poverty and the fact that many rural communities cannot afford medicinal facilities, the researchers who investigated medicinal plant sellers are now involved with them in a partnership which seeks to cultivate medicinal plants as crops. The advantage of this approach is that the cultivation of medicinal plants 
as crops makes it easier to develop and improve strains of plant life, while reducing the need for wild collection. Wild collection exposes women to dangerous situations, such as rape and being attacked by wild animals.

\section{References}

[1] Macía, M.J., García E. and Vidauirre P.J. Ethnobotanical study of medicinal plants traditionally used in the Arribes del Duero, western Spain Journal of Ethnopharmacology 97(2), pp. 337-350, 2004

[2] Silori, C.S. and Badola R. Medicinal plants cultivation and sustainable development. A Case Study in the Buffer Zone of the Nanda Devi Biosphere Reserve, Western Himalaya, India. Mountain Research and Development 20 (3), pp. 272-279, 2000.

[3] Ndawonde, B.G., Zobolo, A.M., Dlamini, E.T. and Siebert, S.J. A survey of plants sold by traders at Zululand muthi markers with a view to selecting popular plant species for propagation in communal gardens. African Journal of Range and Forage Science, 24(2), pp. 103-107, 2007.

[4] Williams V.L., Witkowski T.F. and Balkwill S. Volume and financial value of species traded in the medicinal plant markets of Gauteng, South Africa. International Journal of Sustainable Development and World Ecology: 14 pp. 584-6034, 2007.

[5] Mander, M. The marketing of indigenous medicinal plants in South Africa: A case study in KwaZulu Natal. Food and Agricultural Organisation (F.A.O): Rome, 151 pp, 1998.

[6] Hutchings, A. Zulu Medicinal Plant: An Inventory. University of Natal Press: Pietermaritzburg, 1996.

[7] Pooley, E. The completed fields guide to trees of Natal Zululand and Transkei. Natal Flora publication Trust: Durban, 1993.

[8] Golding, J. S. (eds). Southern African Plant Red Data Lists. South African Botanic Diversity Network Report Series No. 14. National Botanic Institute: Pretoria, pp. 43-53, 2000.

[9] Zobolo, A.M and Mkabela Q.N. Traditional knowledge transfer of activities practiced by Zulu women to manage medicinal and food plant gardens. African Journal of Range \& Forage Science 23, pp. 77-80, 2006.

[10] Gorjestani, N., Indigenous knowledge for Development: Opportunities and Challenges. Proc. of UNCTA D Conference on Traditional Knowledge: Geneva, 2000. 